\title{
COVID-19 as a Catalyst for the (Re-) Constitutionalisation of International Law
}

\author{
One Health - One Welfare
}

Anne Peters

There is a single species that is responsible for the COVID-19 pandemic - us. ${ }^{1}$

How many and who must die before international law responds? COVID-19 starkly illustrates how a virus affects all, but in an extremely uneven way. The disease hits with disproportionate negative effects the poorer countries, and in each and every country, the poorer populations. ${ }^{2}$ COVID-19 is thus exacerbating the cleavage between rich and poor, the wealth disparities inside States and across States. ${ }^{3}$ The indigent have got worse, the better off have thrived ${ }^{4}$ (sec. 1 ). COVID-19 is also a reminder that diseases have always been a companion, both driver and outcome of international relations, now globalisation. In fact, the foundations of international law have been laid by infecting the others. Diseases, notably zoonoses, have also stimulated institution-building on the international plane (sec. 2).

1 Josef Settele and others, 'COVID-19 Stimulus Measures Must Save Lives, Protect Livelihoods, and Safeguard Nature to Reduce the Risk of Future Pandemics' (The Intergovernmental Science-Policy Platform on Biodiversity and Ecosystem Services, 27 April 2020) <https:// ipbes.net/covidigstimulus> accessed 18 March 2021.

2 WHO, WHA, 'COVID-19 response', Second plenary meeting, A73/VR/2 (Doc. 73.1. of 19 May 2020), Preamble, 'Recognizing that the Covid-19 pandemic has a disproportionately heavy impact on the poor and the most vulnerable, ....

3 CESCR, 'Statement on the coronavirus disease (COVID-19) pandemic and economic, social and cultural rights' (UN Doc. E/C.12/2020/1 of 17 April 2020) paras 6-7.

4 World Bank Group, Poverty and Shared Prosperity 2020: Reversal of Fortune (World Bank 2020); PricewaterhouseCoopers and uBs (Switzerland), Riding the Storm: Market Turbulence Accelerates Diverging Fortunes (Billionaires Insights, PwC and UBS 2020).

(C) ANNE PETERS, 2022 | DOI:10.1163/9789004472365_010

This is an open access chapter distributed under the terms of the CC BY-NC-ND 4.o license. Peters - 9789004472365 
Acknowledging that international law has contributed to harming people, animals, and the planet, this essay presupposes that it can be a force for good. Based on this premise, I argue in favour of an activation of international law's positive potentials. The crisis should be used as an opportunity for the modification and operationalisation of the so-far underdeveloped One Health approach, informed by the international constitutional principle of solidarity (sec. 3).

This is how three females experienced the first wave of CoviD-19 in the spring of 2020 .

For an academic in a rich and well-managed State, call her Marie, the border closure between Germany and Switzerland on Monday morning, 16 March 2020 at 8.00 was an extraordinary event. Marie had just spent one week of holidays in the Swiss mountains with the family. When she returned the key of the rented chalet in the agence immobilières, telephones were constantly ringing there. Tourists were inquiring about the situation, because on that day, Saturday, all skiing facilities in Switzerland had closed, and the winter season was terminated prematurely.

Home in the city of B on Sunday, Marie received a WhatsApp message from her neighbour in her house in the German city of $\mathrm{H}$, telling her that the border would be closed next morning. Because Marie did not have her German identity card with her, she decided immediately to go back to H. This was a tough decision because she had an appointment with the veterinarian for her moribund cat on Monday early morning, and Marie had planned to return to her office in $\mathrm{H}$ only after that. Nevertheless, she packed her small bag and boarded the train on Sunday afternoon. Crossing the border was a bit spooky. Around midnight, her husband called her on the phone and told her that the cat had died (at the age of almost 18). For Marie, CoviD will always be connected with her failure to accompany that death.

The next weeks of strict lockdown were paradisiacal. Everything was totally calm, all trips and meetings cancelled. Following something like a recommendation of the German minister of health, Marie stayed in self-confinement for 14 days. Zoom was not yet known in her quarters then. The weather was unusually cold and sunny. Instead of submitting her book manuscript in a rush she sat two weeks just polishing it, going out for a solitary walk in the evenings.

She wished she had known more about her great-grandfather who had died from the so-called Spanish flu in 1917 at the age of forty-something. He had left 
two young daughters, one of whom was Marie's grandmother, who both studied medicine (among the very first female students) in Berlin at the Humboldt university. Due to their father's premature death they had to finance their studies themselves by working in factories. Marie had never worked in factory nor financed her studies by herself. She had no reason to fear a flu anymore. Nevertheless, she decided to get a flu shot offered for free by her employer. At no point Marie felt that her life was in danger, not even her lifestyle.

Merait, a 55 year old textile worker in Bangladesh, experienced the pandemic differently. She lives in the slum-like suburbs of the city of D. When she arrived at the factory on 23 March, she was informed by the local manager that the plant would be temporarily shut down, and that all workers should just go home until they would be called back, and that they would be paid. She received her salary for the rest of the month and has been waiting since for the call, without getting any money.

Together with a group of colleagues, she turned to the local union which had already helped her sister, likewise a textile worker, seven years ago, after the big fire in the firm. ${ }^{5}$ But this time, no compensation or reparation was in sight. The lay-offs were perfectly lawful, based on the economic emergency. Orders for clothes worth millions of Euro had been cancelled by the European and US-American client firms. ${ }^{6}$

Merait missed her mother. Mother had celebrated her 8oth birthday on 25 March. But the week after she had developed a nasty cold, which forced her to stay in bed, and probably became a pneumonia. They did not even go to the hospital which was overrun with Covid patients. Maybe Merait's mom also had Covid but actually they never knew. She had breathing problems and one morning did not wake up anymore.

Luckily, the children were already grown-up. Merait's son normally sold plastic toys at the cross-roads in the nearby metropole. When the national lockdown was proclaimed he walked the 100 kilometres back to the town of D on foot to join the family. It took him three days to reach home. Since then, he

5 Cf. the Sustainability Compact for Continuous Improvements in Labour Rights and Factory Safety in the Ready-Made Garment and Knitwear Industry in Bangladesh (a joint declaration of the government of Bangladesh, the EU and ILO of 8 July 2013) and the Ready-Made Garment Sustainability Council, established on 14 January 2020.

6 Some of the firms later committed to pay in full for orders completed and in production. See 'COVID-19 Tracker: Which Brands Are Acting Responsibly towards Suppliers and Workers?' (Workers Rights Consortium, 17 December 2020) <https://www.workersrights.org/issues/ covid-19/tracker/> accessed 18 March 2021. 
has been spending his days queuing up in front of the local job centre, so far without success.

Merait's daughter was married off last year. But in the lockdown, her husband's temper soured. When his wife complained about money he replied that the dinner was not good and even threw a plate at her.

Posters had been hung up in the neighbourhood, showing pictures about handwashing, masks and social distancing. The community service distributed soap and masks. However, the soap bar lasted only two weeks. The water stations in the neighbourhood were always crowded. Merait's husband decided to discontinue the TV in order to save money. Merait had no smartphone of her own and was therefore cut off from the news. She could not sleep and wondered how long the lockdown would go on.

The third story is about Minkie, a small animal with beautiful, black, soft, and glossy fur. Minkie did not feel the lockdown. She was confined all her life (which lasted five months) in a cramped cage anyway. She is or rather was one of 4.5 million minks kept in 128 mink farms in the Netherlands. Minkie got covid but she did not develop symptoms. She may have felt a bit weak, but because she did not have any space to move nobody noticed. It is unclear who was sick first: the worker who handled the machines that spit out the food, the worker who cleaned the waste, or Minkie. In any case, one worker infected a mink, the mink infected others, and the disease spread over the factory which held 35,00o minks. Covid circulated not only across one but across 27 farms. What is clear is that a minkhuman transmission took place in whatever direction. ${ }^{7}$

The local veterinary agencies decided quickly: Minkie was gassed, together with 1.1 million companions. It was not done the usual way, by electrocution through the anus, but by carbon monoxide. This activity is not called murder, although it is a premeditated taking of life for profit. It is not even called killing but just 'culling'. The episode sped up the phasing-out of the mink farms in the Netherlands. ${ }^{8}$ Parliament adopted a law prohibiting the ugly business, coupled

7 wHo, 'Covid-19 Virtual Press Conference' (22 June 2020) <https://www.who.int/docs/ default-source/coronaviruse/transcripts/virtual-press-conference---22-june---covid -19.pdf?sfvrsn=6da8bbf7_2> accessed 27 August 2021. See also Statement of the Dutch government of 19 May $2020<$ https://www.government.nl/latest/news/2020/05/19/new-results -from-research-into-covid-19-on-mink-farms $>$ accessed 18 March 2021.

8 The closure of the Dutch mink farms will most likely boost the farms in Denmark, Poland, and China (the three biggest mink fur producing countries), until a global prohibition is imposed, or import bans on mink products are issued by countries with market-power, or consumers altogether stop buying mink fur products. 
with financial compensation of the fur-farmers. ${ }^{9}$ Of course, not 1.1 million deaths mattered, but the profit lost over 1.1 million corpses, and the infections of humans.

What Minkie never knew, of course, was that in Denmark, which produced 17 million mink pelts per year, a novel variant of COVID-19 broke out, infecting at least 214 humans and uncounted minks. This led to the immediate culling of all animals. ${ }^{10}$ The news wrote about a 'death knell'11 - but not of more than 17 million minks but of 'the industry.'

These three life-and-death-stories are fictitious, their bits and pieces were taken from the news. The only thing they have in common is the virus. It is not the first time in history that an animal-borne virus disrupts the lives of entire populations.

\section{Diagnosis: Once Again a Disease Drives the Development of International Law}

COVID-19 is a zoonosis, i.e. an infectious disease caused by a pathogen that has jumped from a non-human animal to a human animal and from there spreads to other humans. ${ }^{12}$ Well known recent outbreaks of zoonoses in human society were HIV in the 1980 os (transmitted from monkeys), the highly pathogenic avian influenza (HPAI, the so-called bird flu) that was transmitted to humans

9 Tweede Kamer der Staten-Generaal, 28 286, No. 1112, Dierenwelzijn Motie van de leden Geurts en Bromet over een fatsoenlijke stopregeling voor de nertsenhouderij, proposed 10 June 202O, adopted 23 June 2020. See the judgment by Hoge Raad, Uitspraak, 16 December 2016, Eerste Kamer 16/oog21, Lz/EE. See also Katharina Braun, 'COVID-19, people, and other animals', (Völkerrechtsblog, 12 November 2020) <https://voelkerrechtsblog.org/ covid-19-people-and-other-animals/> accessed 17 April 2021.

10 Press conference on the statement of the Danish Prime Minister of 4 November 2020 $<$ https://www.regeringen.dk/nyheder/202o/danmarks-minkbestand-aflives-grundet -mutation-af-coronavirus/> accessed 16 April 2021. See also who, 'SARS-CoV-2 mink-associated variant strain - Denmark' <https://www.who.int/emergencies/disease-outbreak -news/item/2020-DON301> accessed 27 August 2021.

11 Nikolaj Skydsgaar, 'Denmark tightens lockdown in north, mink cull devastates industry' Reuters (London, 5 November 2020) <https://www.reuters.com/article/health -coronavirus-denmark-mink/denmark-to-lock-down-regions-after-mutated-coronavirus -traced-to-minks-idUSKBN27L11 > accessed 18 March 2021.

12 We do not yet know whether the novel virus originated from the wild animal market in Wuhan or from the bat laboratory next to the market. But what is obvious is that CoviD19 has come upon us as a result of human use and abuse of animals. See seminally on the governance aspects of zoonoses: William Karesh and others, 'Ecology of zoonoses: natural and unnatural histories' (2012) 380(9857) The Lancet 1936. 
from ducks and geese in 1996, and sARs (probably from bats and civet cats) in $2003 .{ }^{13}$

But zoonoses go back in history, to the rise of agriculture thousands of years ago. At that time, the diseases of cows, pigs, geese, ducks, and many other species of animals that were domesticated in Europe befell humans and became what we now call measles, tuberculosis, smallpox, flu, and so on. ${ }^{14}$

Conquest and colonisation, constitutive for international law as we know it today, began with zoonoses. Following Columbus' arrival in the 'new World', about 90 to 95 percent of the indigenous populations in the Americas were killed by measles, smallpox, and influenza carried by the Europeans. ${ }^{15}$ The European weapons, important as they were for the destruction of the American political units and for the establishment of colonial empire, 'paled' against 'the real killer that made European victory possible' - the European germs that were initially spread unwittingly but later employed deliberately for extermination purposes. ${ }^{16}$ The overpowering and supplanting of local populations by European immigrants who were initially very few in numbers 'might not have happened without Europe's sinister gift to other continents - the germs evolving from Eurasia's long intimacy with domestic animals.'17

Besides this germ warfare, animals and a food-ideology were an integral part of the colonial and neo-colonial projects. The Europeans spread stories of the Indigenous' cannibalism which justified not only the forced education of the 'barbarous' but also the importation of cattle as a source of animal food. ${ }^{18}$ Through this 'animal colonialism', the colonisers destroyed not only the local populations, but also the local fauna, flora, and the traditional livelihood. ${ }^{19}$

13 According to Wiebers and Feigin, three out of four emerging diseases are zoonoses: David Wiebers and Valery Feigin, 'What the COVID-19 crisis is telling humanity' (2020) 5(30) Animal Sentience 1 <https://www.wellbeingintlstudiesrepository.org/cgi/ viewcontent.cgi? article $=1626 \&$ context $=$ animsent $>$ accessed 18 March 2021.

14 Jared Diamond, Guns, Germs, and Steel: The Fates of Human Societies (W.W. Norton 1997) 195-214.

15 Noble David Cook, Born to Die:Disease and New World Conquest, 1492-1650 (CuP 1998) 206; Diamond (n 14) 210-213. In contrast, the 'new world' had no lethal crowd diseases at all. Jared Diamond explains the absence of infectious diseases in Indian populations which would have been able to infect Spaniards with less contacts between livestock and humans in the Americas (in comparison to intense co-habitation of livestock and humans in Europe and Asia): ibid 213.

$16 \operatorname{Cook}\left(\mathrm{n}_{15}\right) 205,213$.

17 Diamond (n 14) 214.

18 Anthony Pagden, 'The Forbidden Food: Francisco de Vitoria and José de Acosta on Cannibalism' (1981) 13 Terrae Incognitae 17.

19 Mathilde Cohen, 'Animal Colonialism: The Case of Milk' in Anne Peters (ed), Studies in Global Animal Law (Springer 2020) 35-44. 
Zoonoses have continued to drive the development of international law. The presence of lethal tropical diseases in Africa, Asia, and Indonesia offers one explanation why the European conquest and colonial portioning of those areas was accomplished only 400 years later than the European apportionment of the Americas. ${ }^{20}$

The recurring Cholera pandemics in the 19th century gave rise to one of the first proto-international organisations, the Conseil Supérieur de Santé, established in Constantinople in $1838 .{ }^{21}$ That Council was founded by a decree of the Ottoman Sultan, but the majority of the 18 to 20 members were delegates of the foreign powers with embassies in the city. In 1870, the Council had around 800 staff. The task of this hybrid, internationalised body was to coordinate several hospitals, oversee sanitary offices and secondary observatories. ${ }^{22}$

Another early international organisation is the Office International des Epizooties/World Organisation for Animal Health (OIE), founded in 1924 by 28 States. $^{23}$ Its narrow original objective was to promote international cooperation in controlling the spread of zoonoses notably in the context of transboundary live animal trade. ${ }^{24}$ It has since then evolved significantly and has in 2002 extended its mandate from animal health to include animal welfare. ${ }^{25}$

$20 \quad$ Diamond (n 14) 214.

21 After the foundation in 1838 , a 'Règlement organique du Conseil de santé à Constaninople pour les provenances de mer' was signed on 10 June 1839. This règlement was filed in the international Treaty Series: F. Murhard (ed) Martens Nouveau Receuil (Dieterich Goettingen 1842) vol. $16,2^{\text {nd }}$ part, 920-26. According to its additional Article, the règlement was the fundamental and organisational act of the Council ('fera foi comme acte organique et fondamental').

22 Jean-David Mizrahi, 'Politique sanitaire et impérialisme à l'heure de la révolution pastorienne: Le Conseil sanitaire de Constantinople 1838-1923', in Walid Arbid et al. (eds), Méditerranée, Moyen-Orient: Deux siècles de relations internationales. Recherche en hommage à Jacques Thobie (L'Harmattan 2003) 221-242 (esp. 222-223). See for the complicated mixed status: Benno Toll, Der oberste Gesundheitsrat von Konstantinopel in seiner völkerrechtlichen Bedeutung (Piloty 1922) who characterises the Council as an Ottoman agency which involved foreign delegates because otherwise the capitulations exempted foreigners from the Ottoman jurisdiction. Toll qualifies the connected 'quarantine association' as an international body without international legal personality (ibid 63-67).

23 International Agreement for the Creation of an Office International des Epizooties in Paris, with Appendix: the Organic Statutes of the Office International des Epizooties, of 25 January 1924 (57 LNTS 135).

24 Organic Statutes (n 23) Art 4.

25 International Committee of the OIE, 'Animal Welfare Mandate of the OIE', Resolution No. XIV of May 2002 (in OIE Doc. 70 GS/FR - PARIS, May 2002, 31 et seq.), based on: OIE, Third Strategic Plan 2001-2005 (Paris, OIE 2002), 23, point 6. 
These historical fragments show how diseases, notably zoonoses, impacted on international transactions and how they boosted the building of international governance structures. This trajectory can easily go on. Theoretically, coviD-19 could trigger, for example, a global vaccine development and distribution programme which could in turn be a model for the creation of other so-called global public goods. ${ }^{26}$ I submit that the momentum should be seized.

\section{Remedy: One Health as an International Constitutional Principle}

COVID-19 compels us to recognise the idea of One Health as a full-fledged principle of international law, to adapt it to the current needs, and to operationalise and implement it fully.

\subsection{One Health in Response to Zoonoses}

In its May 2020 meeting on the 'COVID-19 response', the World Health Assembly requested the wHо General Director to apply the 'One-Health Approach' and to continue to work closely with the OIE and the FAO in order 'to identify the zoonotic source of the virus' which would allow 'targeted interventions and a research agenda to reduce the risk of similar events occurring. ${ }^{27}$

The One Health approach is defined in a recent UNEP publication as the collaborative effort across multiple disciplines to attain optimal health for people, animals and the environment. This approach has emerged as a key tool for preventing and managing diseases occurring at the interface of human, animal and environment health. ${ }^{28}$ The One Health paradigm came up in the aftermath of the 2003 outbreak of SARs, a zoonotic disease transmitted probably from bats, too. The veterinarian and activist Dr William B. Karesh seminally wrote that ' $[\mathrm{g}] \mathrm{lobal}$ health will not be achieved without a shift from the expert-controlled, top-down paradigm that still dominates both science and

26 The German Chancellor Merkel spoke of the vaccine as a 'globales öffentliches Gut': Press Conference of 24 April $2020<$ https://www.bundeskanzlerin.de/bkin-de/ aktuelles/pressestatement-von-bundeskanzlerin-merkel-im-rahmen-der-who-spenden -videokonferenz-174696o > accessed 22 April 2021.

27 WHO, WHA, 'COVID-19 response' (n 2) para 9(6).

28 United Nations Environment Programme (UNEP) and International Livestock Research Institute (lead author Delia Grace Randolph), Preventing the Next Pandemic: Zoonotic diseases and how to break the chain of transmission (Kenya 2020) 37. 
medicine. A broader, more democratic approach is needed, one based on the understanding that there is only one world - and only one health.'29

Today, One Health is no longer just a buzzword but informs legal decisionmaking. For example, the Islamabad High Court mandated the release of zoo elephants with the argument that 'the current pandemic crisis (...) has highlighted the interdependence of living beings on each other, (...) and (...) it has conspicuously brought the essence, meaning and significance of 'life' into the spotlight.' ${ }^{30}$ This can be read as an implicit application of the One Health principle. Another example is the Convention on Biodiversity (СвD) СоP decision of 2018 'Health and Biodiversity'31 which was imbued by the One Health approach albeit without mentioning the word.

A One Health approach is inevitable facing the ongoing human-induced explosion of zoonoses. According to the Intergovernmental Platform on Biodiversity and Ecosystem Services (IPBES), '[a]n estimated 1.7 million currently undiscovered viruses are thought to exist in mammal and avian hosts. Of these, 540,000 - 850,000 could have the ability to infect humans. ${ }^{32}$ As the Lancet pointed out: 'New zoonotic diseases are emerging and re-emerging at an exponentially increasing rate. (...) Not all zoonotic diseases become pandemics, but most pandemics are caused by zoonoses and they have become characteristic of the Anthropocene era. ${ }^{33}$ The reasons for the growing risk of zoonotic pandemics are the exponentially increasing anthropogenic changes of the earth system. These include land use and extraction, the clearing of land for farming and grazing, the intensive, industrialised livestock farming, and increased human encroachment into wildlife habitats. ${ }^{34}$ Also deforestation frees microbes many of which have not yet been encountered by people. A key factor for the great acceleration of the spread of zoonoses is the exponential intensification of international travel and trade, key components of globalisation. UNEP sums this up as follows: 'The frequency of pathogenic microorganisms jumping from other animals to people is increasing due to unsustainable

29 William B. Karesh and Robert A. Cook, 'The Human-Animal Link' (2005) 84 Foreign Affairs 38 .

30 Islamabad High Court, Islamabad (Judicial department) W.P. No. 1155/2019 Islamabad Wildlife Management Board through its Chairman v. Metropolitan Corporation Islamabad through its Mayor \& 4 others, judgment of 21 May 2020.

$31 \mathrm{CBD} / \mathrm{COP} / \mathrm{DEC} / 14 / 4(2 \mathrm{O} 18)$.

32 IPBEs, Workshop on Biodiversity and Pandemics, Workshop Report of 29 October 2020 (unredacted and not peer reviewed version) 5 .

33 Editorial, 'Zoonoses: beyond the human-animal-environment interface' (2020) 396(10243) The Lancet 1. IPBES (n 32) 6 . 
human activities. Pandemics such as the CoviD-19 outbreak are a predictable and predicted outcome of how people source and grow food, trade and consume animals, and alter environments. ${ }^{35}$

\subsection{Expansion of the One Health Approach in Three Dimensions}

Understanding the reasons for the proliferation of zoonoses is the key to combating them. The UN Framework for the Immediate Socio-economic Response to COVID-19, published in April 2020, inter alia asks for 'efforts to arrest ecosystem encroachments and harmful practices, restore degraded ecosystems, close down illegal trade and illegal wet markets', and here refers to the three relevant conventions: The Convention on International Trade in Endangered Species of Wild Flora and Fauna, (CiTES), the Convention on Migratory Species (CMS), and the Convention on Biological Diversity (СвD). ${ }^{36}$ The UN Framework thus implies a One Health-based approach.

A robust response moreover demands the intensification and modification of the One Health approach in the following three dimensions. First, One Health must take livestock more decisively into its purview, beyond the already acknowledged issue of antimicrobial resistance. Inspiration can be found in a 'solutions scan', published by a Cambridge-led international team of wildlife and veterinary experts in June. It gives a list of options for reducing the risk of another pandemic. ${ }^{37}$ The team mentions, inter alia, the following: 'Reduce animal density both within and between farms;' '[t]ake measures to reduce stress in farmed animals including maximum permissible stocking densities and other basic welfare standards;' 38 '[i]ntroduce licencing or certification system for the transport of live animals or animal parts, to ensure hygiene and welfare standards are adhered to. ${ }^{39}$ The group finally mentions the options to '[p]romote the development and commercialisation of synthetic alternatives (e.g. synthetic fur, leather or lab-created meat)' and to '[i]nfluence consumer attitudes to increase acceptability of lower-risk substitute products (e.g. plants or synthetic substitutes for food, clothing or medicine instead of

\footnotetext{
35 UNEP 2020 (n 28) 7.

36 UN Framework for the Immediate Socio-economic Response to COVID-19 (United Nations: April 2020) 28, see also 35 .

37 Silviu O Petrovan and others, 'Post COVID-19: a solution scan of options for preventing future zoonotic epidemics' (OSF 202O). The 'solutions scan' was initiated as a collaboration between BioRISC (the Biosecurity Research Initiative at St Catharine's College, Cambridge), Conservation Evidence based in the Department of Zoology, University of Cambridge, and numerous other researchers worldwide.

38 ibid 33 .

$39 \quad$ Petrovan and others $(\mathrm{n} 37) 38$.
} 
animal products, particularly those from high-risk species). ${ }^{40}$ According to the IPBES, '[p] andemic risk could be significantly lowered by promoting responsible consumption and reducing unsustainable consumption of commodities from emerging disease hotspots, and of wildlife and wildlife-derived products, as well as by reducing excessive consumption of meat from livestock production. ${ }^{41} \mathrm{~A}$ well-known geophysicist points out: 'To prevent future pandemics (...) we must rethink our relationship with animals, and livestock in particular. The main upshot of this rethinking is the need to eat less animal-based food, including markedly reducing our consumption of beef'.42

Second, additional international institutions and international legal regimes must be drawn in. The One Health-oriented collaboration of the above-mentioned three international organisations (FAO, OIE, and WHO) began in 2010 with a tripartite concept note that lays the basis for their 'coordinating global activities to address health risks at the animal-humanecosystems interfaces. ${ }^{43}$ Besides these three organisations, further institutions and regimes should be directly involved, notably the WTо (notably via the Codex Alimentarius Commission and the sps-Agreement), the Convention on Biodiversity (СвD), ${ }^{44}$ and the Convention on International Trade in Endangered Species of Wild Fauna and Flora (CITES).

In addition, CITES would need to be expanded in scope to domestic trade with international repercussions. The necessity is illustrated by Covid-19. The pangolins that were probably an intermediate host for the CoviD-19 between the bats and humans are listed in Appendix I of CiTES, which basically prohibits all international trade in the species. ${ }^{45}$ However, CITES as it stands does

$40 \quad$ Petrovan and others (n 37$) 42$.

41 IPBES (n 32) 6.

42 Gidon Eshel, 'Pandemic leadership failures and public health, Commentary on Wiebers \& Feigin on Covid Crisis' (2020) 5(30) Animal Sentience 365 .

43 FAO, OIE, WHO, 'The FAO-OIE-WHO collaboration, Sharing responsibilities and coordinating global activities to address health risks at the animal-human-ecosystem interfaces' (April 2010) 3 <https://www.who.int/influenza/resources/documents/tripartite _concept_note_hanoi_o42011_en.pdf?ua=1> accessed 27 April 2021: 'This tripartite relationship envisages complementary work to develop normative standards and field programs to achieve One Health goals'.

44 Convention on Biological Diversity (adopted 5 June 1992, entered into force 29 December 1993) 1760 UNTS 79 .

45 CoP18 Doc. 75 (2019) - Cites, Species specific matters, Pangolins (Manis Spp.): 'At the 17th meeting of the Conference of the Parties ( $\mathrm{CoP}_{17}$, Johannesburg, 2016), all eight species of pangolin were transferred from cites Appendix II to Appendix I.' 
not apply to the inner-Chinese trade with endangered species. ${ }^{46}$ A dynamic interpretation of the treaty in the direction of covering all trade in endangered species that deploys substantive transboundary effects would theoretically be possible but likely to be perceived as illegitimate by State parties. ${ }^{47}$ Therefore, the elaboration of an additional protocol in that sense would be advisable.

Third, the COVID crisis suggests that the One Health Approach which has so far addressed the human-animal-environmental-interface needs to be conceptually developed so as to encompass a North-South dimension. One Health should be understood as demanding a North-South solidarity in prevention and treatment of infectious diseases. One Health should thus comprise both a trans-species perspective and a trans-society perspective. This also implies that the One Health approach which currently unites medical, veterinary, and environmental expertise needs to be complemented by social science, economic, ethical, and legal expertise for addressing better the social, economic, and governance causes of the emergence and spread of zoonoses.

The legal argument providing the basis for this 'social' extension of the One Health approach is the principle of solidarity. In parallel to a whole range of nationalist reflexes and actions, pandemic-related legal pronouncements have invoked global solidarity. Both coviD-related UN-General Assembly Resolutions appeal to solidarity, ${ }^{48}$ and the wHo Assembly does it, too. ${ }^{49}$

This new talk (some might say 'cheap talk') on global solidarity can build on a pre-existing textual basis which has however not given firm contours to the concept. ${ }^{50}$ Despite this vagueness, solidarity has been identified as an

46 Convention on International Trade in Endangered Species of Wild Fauna and Flora (CITES) (adopted 3 March 1973, entered into force 1 July 1975) 993 UNTs 243 (emphasis added).

47 Cites Art. I lit. c) defines 'trade' as 'export, re-export, import and introduction from the sea'. Cf. also Willem Wijnstekers, The Evolution of CITES (11 ${ }^{\text {th }}$ edn, CIC - International Council for Game and Wildlife Conservation 2018) 6o.

48 'Recognizing also that the CoviD-19 global pandemic requires a global response based on unity, solidarity and multilateral cooperation, [...]' (UN GA res. 74/270 and res. 74/274; emphasis added).

49 WHA (n 2), 'Calls for, in the spirit of unity and solidarity, the intensification of cooperation and collaboration at all levels in order to contain and control the coviD-19 pandemic and mitigate its impact'.

50 'Solidarity' is mentioned in numerous hard and soft texts of international law. See for the latest document in the relevant process of the Human Rights Council: Draft declaration on the right to international solidarity and Report of the Independent Expert on human rights and international solidarity (UN Doc. A/HRC/35/35 of 25 April 2017). 
'emerging structural principle of international law'. ${ }^{51}$ Moreover, given the fundamental importance and the principle's firm constitutional entrenchment in many State constitutions of the world, ${ }^{52}$ solidarity has not without merit been qualified as a 'constitutional' principle of the international legal order. ${ }^{53}$

The existence of a political, moral, and to a limited extent legally relevant discourse both on solidarity and on One Health suggests a mutually harmonious interpretation of both principles. ${ }^{54}$ One Health can be interpreted in the light of solidarity, and solidarity in the light of One Health. One Health thus becomes a trans-social concept, and solidarity becomes a trans-species solidarity. But of course, both One Health and solidarity can be no more than a rough guideline pointing in the direction of a commitment to work collectively towards a shared goal (combatting the virus, stopping encroachment of wildlife habitat and high-density farming), and towards sharing benefits (e.g. the vaccine) fairly. ${ }^{55}$ Along that line, One Health flows into a trans-species and trans-social 'One Health - One Welfare'-perspective, as espoused notably by the African Union. ${ }^{56}$

$5^{1} \quad$ Rüdiger Wolfrum, 'Solidarity amongst states: an emerging structural principle of international law', in Pierre-Marie Dupuy and others (eds), Common Values in International Law: Essays in Honour of Christian Tomuschat (Engel 2006) 1087-1101.

$5^{2}$ See for the EU i.a. the European Charter of Fundamental Rights, Title IV 'Solidarity' (Articles 27-38). See for German constitutional law: Uwe Volkmann, Solidarität:Programm und Prinzip der Verfassung (Mohr Siebeck 1998).

53 Karel Wellens, 'Revisiting Solidarity as a (Re-)Emerging Constitutional Principle: Some Further Reflections' in Rüdiger Wolfrum and Chie Kojima (eds) Solidarity: A Structural Principle of International Law (Springer 2010) 3-54. See for the full argument Anne Peters, 'Global Constitutionalism: The Social Dimension', in Takao Suami and others (eds), Global Constitutionalism from European and East Asian Perspectives (CUP 2018) 277-350.

54 Such systemic integration of fundamental principles strengthens the coherence of the international legal order and can therefore be seen as aspects of its procedural constitutionalisation (Anne Peters, 'The Refinement of International Law: From Fragmentation to Regime Interaction and Politicization' (2017) 15 ICON 671).

55 Cf. Andrew Mason, 'Solidarity', Routledge Encyclopedia of Philosophy (Version 1.o, Taylor and Francis 1998) <https://www.rep.routledge.com/articles/thematic/solidarity/v-1> accessed 27 April 2021.

56 African Union - InterAfrican Bureau for Animal Resources, 'Animal Welfare Strategy for Africa' (2017) 11: 'principles of one health and one welfare'. See in scholarship R. García Pinillos, One Welfare: A Framework to Improve Animal Welfare and Human Well-being (CABI 2018). In scholarship, the idea has been further extended to a 'one rights'-approach. See Saskia Stucki and Tom Sparks, 'The Elephant in the (Court)Room: Interdependence of Human and Animal Rights in the Anthropocene' (EJIL:Talk!, 9 June 2020) <https:// www.ejiltalk.org/the-elephant-in-the-courtroom-interdependence-of-human-and -animal-rights-in-the-anthropocene/> accessed 17 April 2021. 
Simply invoking One Health can of course not stop the human encroachment on wildlife habitat. Quite to the contrary, the global public's focus of attention on COVID-19 has allowed environmental crimes to go unchecked. For example, the deforestation of the Brazilian rainforest has peaked again in the spring of $2020 .{ }^{57} \mathrm{But}$, as always, offering a legal vocabulary to address injustice can form one (small) building block for a path towards change.

The CoviD-19 crisis erupted in a political climate dominated by nationalism, populism, and international law-scepticism. It has accelerated these pre-existing factual and accompanying legal trends. COVID-19 so far neither produced one single mega-trend nor has it been a legal game changer. This can be viewed as a good thing or as a bad one, depending on whether one places hopes in the law, specifically international law, or not. Facing the virus, '[l] aw can serve as both an enabler and a barrier to global health, equity, and justice. 58

Marie, Merait, and Minkie have so far benefitted from international law in different ways. A BIT facilitated the establishment of the factory which employed Merait but did not oblige the firm to improve its social security scheme. ${ }^{59}$ Had the WHO's explicit recommendation 'against the application of travel or trade restrictions' 60 been followed by Germany, Marie could have

57 Human Rights Watch, “The air is unbearable”: Health Impact of Deforestation-Related Fires in the Brazilian Amazon' (26 August 2020) <https:/www.hrw.org/report/2020/ o8/26/air-unbearable/health-impacts-deforestation-related-fires-brazilian-amazon> accessed 17 April 2021.

$5^{8}$ Alexandra L Phelan and others, 'Legal agreements: barriers and enablers to global equitable COVID-19 vaccine access' (2020) 396(10254) The Lancet 8oo, 8oo.

59 Peter Egger and Michael Pfaffermayer, 'The Impact of Bilateral Investment Treaties on Foreign Direct Investment' (2004) 32 Journal of Comparative Economics 788 . Empirically speaking, the impact is controversial.

6o See, e.g., wHo, 'Statement on the second meeting of the IHR emergency committee regarding the outbreak of the 2019-nCoV' (30 January 2020) <https://www.who.int/ news/item/30-o1-2020-statement-on-the-second-meeting-of-the-international-health -regulations-(2005)-emergency-committee-regarding-the-outbreak-of-novel -coronavirus-(2019-ncov)> accessed 18 March 2021: 'The Committee does not recommend any travel or trade restriction based on the current information available'; wHO, 'Updated WHO recommendations for international traffic in relation to COVID-19 outbreak' (29 February 2020) <https://www.who.int/news-room/articles-detail/updated-who -recommendations-for-international-traffic-in-relation-to-covid-19-outbreak> accessed 18 March 2021: 'WHO continues to advise against the application of travel or trade restrictions to countries experiencing CoviD-19 outbreaks'. The legal basis of these statements are the International Health Regulations which require that the wHo Director General's temporary recommendations 'avoid unnecessary interference with international traffic' 
stayed with the dying cat. A stronger and more legally imbued sense of solidarity would lead Germany to put more money into the vaccination platform COVAX, and improve access to a vaccine for Merait and her family. ${ }^{61}$ Minkie's kinfolk would need an outright international prohibition of fur farming, or at least a radical cap on stocking densities. The insight that human health, a public interest objective, will benefit from such measures, too, would help legalising closures of factories that interfere with property rights. It is the responsibility of Marie and her colleagues to make these arguments.

and that they 'are not more restrictive of international traffic and trade (...) than reasonably available alternatives that would achieve the appropriate level of health protection': International Health Regulations (adopted 23 May 2005, entered into force 15 June 2007) 2509 UNTS 79, Art 15(1) and Art 17(1) lit. d).

61 See 'Covax: The Vaccines Pillar of the Access to Covid-19 Tools (ACT) Accelerator Structure and Principles' (9 November 2020) and other documents: <https://www.gavi.org/ covax-facility\#documents> accessed 18 March 2021. 